\title{
Archipel
}

ARCHIPEL Études interdisciplinaires sur le monde insulindien

99 | 2020

Varia

\section{Alessandra Lopez y Royo. Contemporary Indonesian Fashion: Through the Looking Glass. London and New York: Bloomsbury, 2020, ix-216 pp. ISBN: 978-1-3500-6130-9}

\section{Carla Jones}

\section{OpenEdition}

\section{Journals}

Electronic version

URL: http://journals.openedition.org/archipel/1819

DOI: 10.4000/archipel.1819

ISSN: 2104-3655

\section{Publisher}

Association Archipel

\section{Printed version}

Date of publication: 15 July 2020

Number of pages: $286-289$

ISBN: 978-2-910513-83-2

ISSN: 0044-8613

\section{Electronic reference}

Carla Jones, "Alessandra Lopez y Royo. Contemporary Indonesian Fashion: Through the Looking Glass. London and New York: Bloomsbury, 2020, ix-216 pp. ISBN: 978-1-3500-6130-9", Archipel [Online], 99 | 2020, Online since 02 June 2020, connection on 15 March 2021. URL: http://journals.openedition.org/ archipel/1819 ; DOI: https://doi.org/10.4000/archipel.1819 
aligning himself with Gojek founder Nadiem Makarim (whom in 2019 he made Minister of Education) and other homegrown large tech companies. This, however, creates ambiguity as the President's aspiration for foreign capitals is hindered by constraining regulations.

The last chapter by Michele Ford and Vivian Honan zooms in on Gojek, Indonesia's most popular app-based transport service, and presents a conundrum: on the one hand, consumers' satisfaction means that the company enjoys considerable consumer support - especially during the 2016 clash with conventional motorcycle taxi drivers and taxi drivers -, on the other, the unregulated expansion of app-based transport service is threatening the livelihood of conventional (motorcycle) taxi drivers.

This book thus covers various issues on how Indonesia deals with governance, economy and social life in the digital era. Due to such a wide range, it is understandable that some important themes that are relevant to both the Indonesian and Southeast Asia's contexts have not been adequately delved into. Among these are the intersections between national security and the freedom of information and between the freedom of information and the right to privacy. Many of the chapters mention regulatory problems, yet none touches upon, for example, the complexities of the government having to deal with viral hoaxes which poses security threats on the one hand, and its commitment to the freedom of information on the other. Another example is the recent discourse on the "right to be forgotten", or the right to have private information be removed from internet searches, and how this may impede the freedom of information.

That said, this book represents a pioneering work on Indonesia's response to the digital era. It portrays various opportunities and challenges and shows how the state and the society alike navigate through policies and implementation. I thus recommend this book to policymakers, business practitioners, students and all who study Indonesia and are interested in how disruptive technology influences its politics and economy.

Deasy Simandjuntak ISEAS-Yusof Ishak Institute Singapore and Academia Sinica Taipei

Alessandra Lopez y Royo. Contemporary Indonesian Fashion: Through the Looking Glass. London and New York: Bloomsbury, 2020, ix-216 pp. ISBN: 978-1-3500-6130-9

Indonesian visual and style cultures have proliferated in the past two decades. Art historian, model and fashion critic Alessandra Lopez y Royo's new book Contemporary Indonesian Fashion: Through the Looking Glass offers a first-hand survey of some of the key figures in this period. Her book is a welcome resource for anyone seeking to know more about the institutions, 
individuals and innovations associated with the Indonesian fashion scene, and as such joins a growing collection of analyses of Indonesian visual and political life (cf. Lee 2016; Strassler 2010, 2020). Saturating the book is genuine affection for Indonesian designers and designs. Lopez y Royo is a passionate advocate for the world and tastes she admires.

Rooted in her earlier academic training in dance iconography in Hindu and Buddhist monuments, Lopez y Royo expanded her interest in Indonesian aesthetics through two research visits to Indonesia in 2015 and 2018. She provides readers with a close account of the dramatic growth of the fashion industry, with both Indonesian designers who have gained global cachet and expatriate designers who have chosen to be based in Indonesia. Lopez y Royo argues that the fashion scene has dramatically transformed since the end of the Suharto New Order, a period that has witnessed domestic and international institutional investment in fashion design as a development strategy. Within Indonesia, the growing middle and upper-classes in major cities, especially Jakarta, have framed consumption as leisure, particularly evident in the display of clothing on shoppers and in boutique windows. The Indonesian government has also taken note and has established a new bureau BEKRAF, a wing of the Ministry of Tourism, effectively targeting fashion as a zone for global economic growth. This political and financial focus hopes to move Indonesia beyond low-wage mass garment production and to re-orient the higher-value production of fashion design beyond the wealthy capitals of London, Paris or New York.

Lopez y Royo frames her description of the magazines, fashion show organizations, and shopping venues by interrogating the binary that continues to animate much fashion analysis: the persistent dynamic of cultural borrowing and exoticism. Using the metaphor of a mirror, she invites readers to enter into the double-bind that Indonesian designers themselves experience in refracting their own aesthetic inspiration to fellow urban consumers and to the world. As she argues, "Indonesian contemporary fashion can be held up as a mirror reflecting back and allowing a scrutiny of current globalizing and hegemonizing fashion and beauty discourses" (xxv). Taking Indonesian creativity seriously could "shift the fashion discourse" (xxv) from categories such as center and periphery or rigid fashion systems. In the process, it might even challenge the enduring Orientalist fascination with non-Western fashion as ethnic or national, rather than original and avant-garde, values Western fashion saves for itself even as it appropriates other textile traditions.

In arguing that fashion should not simply be another field through which difference is reinscribed, Lopez y Royo asks readers to recognize that the phrase "Made in Indonesia" can signify world-class style. One of the most detailed and helpful aspects of the book is the description of the history and formation of the two major fashion weeks in the annual fashion cycle in Jakarta, 
Jakarta Fashion Week (JFW) and ID:FW. These alternating semi-annual shows do what fashion shows elsewhere do: display product and women's bodies in spectacular performance-events that are about art, sociality and distinction as much as they are about commerce. Invitations are hard to come by, fashion magazines cover them in close detail, and social media influencers increasingly document them in real time. However, Jakarta fashion shows also take on a uniquely Indonesian festivity, becoming sites for urban consumers to delight in each other's company and reinforce their cosmopolitaneity through a shared appreciation for local designers, even as their own closets are filled with a mix of global and local brands.

Lopez y Royo introduces readers to a range of designers, from established to younger and from high-end to more affordable. Frequent visitors to Indonesia will appreciate the detailed histories and personal interviews with luxury designers Ghea Panggabean, Biyan Wanaatmadja, Sebastian Gunawan, Auguste Soesastro, Tri Handoko Joewono, and Musa Widyatmojo. Each of these designers have made conscious decisions about how to embrace, or avoid, local textile traditions such as batik and ikat. While some have chosen to use local textiles (as Ghea has with tie-dyed jumputan), others have chosen minimalism and eco-friendly styles. Lopez y Royo also profiles edgier designers such as Lulu Lutfi Labibi, a Yogyakarta designer with a national and international following who crafts one-of-kind, unusually shaped garments out of the comparatively humbler textile lurik. She also describes the integration of fashion into activist and artist projects that directly critique dominant conceptions of femininity.

Lopez y Royo offers similarly careful descriptions of the modeling system, the fashion magazine ecosystem, art galleries and the array of shopping malls in Jakarta, as intersecting sites for the production, circulation and consumption of ideas of beauty and self-expression. She traces the formation and growth of Dewi and Femina magazines, as part of the broader Femina Group of publications which have supported JFW. As she notes, in spite of the proliferation of digital commerce and online media, print magazines continue to have audiences in urban and rural communities. Femina, for example, maintains its popular advice columns based on real-life stories from readers in both their print and digital editions. Magdalene, by contrast, is entirely digital, publishes in both English and Indonesian, and openly embraces discussing feminism and politics along with health and beauty. Lopez y Royo's descriptions of the people-watching quality of Jakarta shopping malls, especially Plaza Senayan, Plaza Indonesia and Pacific Place, also capture the complex relationship urban consumers have with malls. Simultaneously loci for acquiring commodities and for air-conditioned socializing, she conveys how young people have mixed feelings about the fact that they have been raised to consider malls their primary leisure venues. Although much of consumer 
culture in malls celebrates the energy and critique that urban youth express, Lopez y Royo's own modeling, blogging and fashion activism has focused on the ageism that saturates the fashion industry in the UK and Europe. This informed her concluding insights that the Indonesian fashion industry has similar biases against representations of the aging or greying female form. Her arguments also resonate with Ayu Saraswati's (2013) careful analysis of the intersection of race and beauty in Indonesia.

Lopez y Royo's personal experience and perspective shape this book most intimately. Her enthusiasm for Indonesian fashion is palpable. While the book is less an analysis than a joyful introduction to a field, Lopez y Royo deftly achieves her primary goal of inviting readers into a large, diverse scene that, as she says, merits much more intellectual and global attention.

\section{References}

Lee, Doreen. 2016. Activist Archives: Youth Culture and the Political Past in Indonesia. Durham: Duke University Press.

Saraswati, Ayu. 2013. Seeing Beauty, Sensing Race in Transnational Indonesia. Honolulu: University of Hawai'i Press.

Strassler, Karen. 2010. Refracted Visions: Popular Photography and National Modernity in Java. Durham: Duke University Press.

Strassler, Karen. 2020. Demanding Images: Democracy, Mediation, and the Image-Event in Indonesia. Durham: Duke University Press.

Carla Jones

Department of Anthropology University of Colorado Boulder

\section{Études régionales}

Rebecca Fanany and Ismet Fanany, The Elderly Must Endure: Ageing in the Minangkabau Community in Modern Indonesia. Singapore: ISEAS - Yusof Ishak Institute, 2018, xii + 309 p. ISBN: 978-981-4818-46-9 (paperback), 978-981-4818-47-6 (pdf).

Anyone at an advanced age certainly experiences ageing as a natural aspect of human existence. Our modern world is facing a significant increase in the number of elderly people as a result of advances in the provision of health services, food quality, and medical research. However, experiencing old age as a cultural phenomenon is highly dependent on the community or country one lives in as a result of diverse local factors, including religion, traditional custom, geographic and socio-cultural environments, and State's political policies.

Indonesia, as many other States in the world, is also facing an increasing number of old persons. In a heterogeneous and multiethnic State such as 